Proc. Estonian Acad. Sci. Geol., 2006, 55, 1, 43-66

\title{
Thelodonts (Agnatha) from the basal beds of the Kuressaare Stage, Ludlow, Upper Silurian of Estonia
}

\author{
Tiiu Märss \\ Institute of Geology at Tallinn University of Technology, Estonia pst. 7, 10143 Tallinn, Estonia; \\ Tiiu.Marss@gi.ee \\ Received 16 November 2005, in revised form 7 February 2006

\begin{abstract}
The thelodont Loganellia cuneata (Gross) is redescribed and new thelodont taxa Paralogania perensae sp. nov., Nethertonodus laadjalaensis sp. nov., and Longodus acicularis gen. et sp. nov. are established. The last taxon belongs to the family Longodidae fam. nov. of Thelodonti but its order is uncertain. This assemblage comes from the Tahula Beds of the Kuressaare Stage, Ludlow, Upper Silurian of Estonia.
\end{abstract}

Key words: Thelodonti, Agnatha, taxonomy, Estonia, Ludlow, Silurian.

\section{INTRODUCTION}

In the course of geological mapping in the 1970s-1980s the Geological Survey of Estonia drilled numerous boreholes on the territory of Estonia. The core samples were given to the palaeontologists of the Institute of Geology for preparation, identification of fossils, biostratigraphical study, and correlation of the core sections. As a result, over 1000 samples with vertebrate microremains were obtained but not all material was studied in detail. The present paper is focused on new thelodonts from the basal beds of the Kuressaare Stage, Ludlow, Upper Silurian of Estonia, recovered from 17 drill cores (Fig. 1).

The subclass Thelodonti includes five orders, Loganelliiformes Turner, 1991, Shieliiformes Märss, Wilson \& Thorsteinsson, 2002, Phlebolepidiformes Berg, 1937, Thelodontiformes Kiaer, 1932, and Furcacaudiformes Wilson \& Caldwell, 1998. All these higher taxa are represented by both articulated specimens and scattered scales (Märss et al. 2002, 2006; Karatajūtè-Talimaa \& Märss 2004). Recently the order Sandiviidiformes was established for the Ordovician-Lower Silurian scale taxa (Märss et al., submitted). In this paper a species of Loganellia Turner from the order Loganelliiformes is redescribed, new species of the 


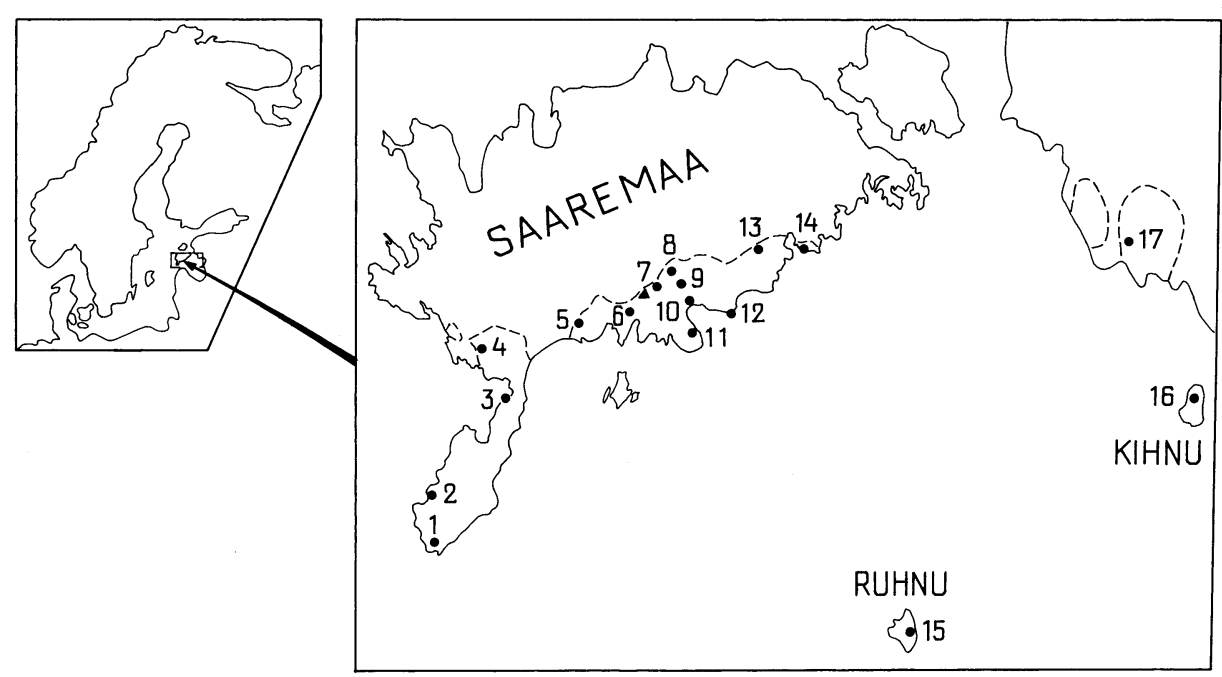

Fig. 1. Western Estonia with islands showing the distribution of the Kuressaare Stage with the location of drill cores (dots) and Laadjala Bridge outcrop (triangle) (from Perens \& Perens 2004). Drill cores: 1, Sõrve-514; 2, Ohesaare-GI; 3, Kaugatuma-GI; 4, Lahetaguse-573; 5, Suurlahe-738; 6, Kuressaare-804 and Kuressaare-GI (= Kingissepa-GI); 7, Tahula-709; 8, Reo-927; 9, Pihtla-816; 10, Sutu-605; 11, Vätta-817; 12, Nässumaa-825; 13, Sakla-GI; 14, Kõiguste-833; 15, Ruhnu-500; 16, Kihnu-526; 17, Varbla-502.

genera Paralogania Karatajūtè-Talimaa and Nethertonodus Märss \& Miller of the order Shieliiformes, and a new species and genus of a new family Longodidae, incerti ordinis, are established. The described vertebrate collection is housed in the Institute of Geology at Tallinn University of Technology under the registration numbers GIT 456 and GIT 232 plus fossil number.

\section{GEOLOGICAL SETTING}

In Estonia the rocks of the Kuressaare Stage have been cored in the Tõstamaa Peninsula, mainland of Estonia, and Saaremaa, Kihnu, and Ruhnu islands. The outcrop area of the stage stretches latitudinally in southern Saaremaa (Fig. 1). The sedimentary rocks of the Kuressaare Stage, overlying the Paadla Stage and succeeded by the Kaugatuma Stage, are subdivided into the Tahula and Kudjape beds. The underlying Paadla Stage is represented by bioclastic limestones, interbedded with bands of marlstones, and coral-stromatoporoid biostromes. The base of the Kuressaare Stage coincides with an increase in the clay component (Perens et al. 1994; Nestor 1997). The lower part of the Tahula Beds of the Kuressaare Stage consist mainly of argillaceous marlstones with interlayers of various bio- and lithoclastic limestones. Higher in the Tahula Beds the limestone interlayers become more frequent, and in the Kudjape Beds nodular argillaceous biomicritic 
limestones with coquinoid interlayers prevail (Perens et al. 1994; Nestor 1997). The lithological change at the Paadla and Kuressaare stage boundary is not very distinct in most cores but in some core sections (e.g., Muratsi-805, Vätta-817, and Nässumaa-825) the boundary is marked by a discontinuity surface (Perens et al. 1994). A bone bed occurs at the base of the Tahula Beds in the Sakla-GI and Sutu-605 cores. The boundary between the Paadla and Kuressaare stages is defined by the appearance of the thelodont Thelodus sculptilis and conodont Ozarkodina remscheidensis aff. scanica (Viira \& Männik 1997, table 43).

In the vertebrate history, the upper Ludfordian (Ludlow, Upper Silurian) second Innovation Event brought in new vertebrate taxa in North America, British Isles, Gotland Island, Severnaya Zemlya, and the Central Urals (Märss 1992; Märss et al. 1998a; Karatajūtė-Talimaa \& Märss 1999; Märss \& Miller 2004). Part of this event corresponds to a stratigraphical hiatus in the northern East Baltic (Märss 1992, fig. 2) where in other areas Thelodus sculptilis Gross and Andreolepis hedei Gross co-occur. The rich thelodont fauna as well as the whole vertebrate assemblage, which appeared at the beginning of Tahula time, was the result of this innovation and favourable environmental conditions. At the end of the Paadla Age and the beginning of the Kuressaare Age, shallow-water lagoonal conditions prevailed on the territory of present-day Saaremaa, with occasional interruptions of sedimentation (Nestor 1997). The Tahula Beds were deposited in regressive sea conditions, and a short-term deepening of the basin took place while the Kudjape Beds were being deposited (Märss 1986, fig. 47; Märss 1992). The increased influx of clay material from land area might have been due to input from a stream (H. Nestor, pers. comm. 2005). The fragile scales, sometimes deposited as bone beds in the marls, were preserved undamaged. No articulated squamations have been found as they were probably disintegrated by waves in that lagoon.

\title{
SYSTEMATIC DESCRIPTION
}

\author{
Class AGNATHA Cope, 1889 \\ Subclass THELODONTI Kiaer, 1932 \\ Order LOGANELLIIFORMES Turner, 1991 \\ Family LOGANELLIIDAE Karatajūtè-Talimaa, 1997 \\ Genus Loganellia Turner, 1990
}

Species content. Loganellia aldridgei Turner, 2000; L. almgreeni Blom, 1999; L. asiatica (Karatajūtè-Talimaa, 1978); L. avonia Turner, 2000; L. cuneata (Gross, 1947); L. einari Märss, 1996; L. exilis Märss et al., 2002; L. grossi (Fredholm, 1990); L. incompta (Karatajūtè-Talimaa, 1990); L. matura Märss \& Karatajūtè-Talimaa, 2002; L. prolata Märss et al., 2002; L. scotica (Traquair, 1898); L. sibirica (Karatajūtè-Talimaa, 1978); L. sulcata Märss et al., 2002; L. tuvaensis (Karatajūtè-Talimaa, 1978); L? unispinata Märss \& Miller, 2004. 
Loganellia cuneata (Gross, 1947)

Plate I, figures 1-21; Plate II, figure 1

For the synonymy before 1986 see Märss (1986).

1986 Logania cuneata (Gross); Märss, pl. 14, figs 2, 3, 5, 11, 13; pl. 15, figs 5-7; text-fig. 15: 1-6, 13-20, 31-37.

2004 Loganellia cuneata (Gross); Märss \& Miller, text-fig. 6.

Material. Some hundreds of scales of which GIT 456-59 to GIT 456-86 were imaged by SEM and GIT 456-119 and GIT 456-120 were used for thin sections.

Occurrence. Scales come from the following drill core intervals: Sõrve-514, 130.8-144.4 m; Ohesaare-GI, 92.60-95.17 m; Sutu-605, 13.4-23.7 m; Reo-927, 6.5-12.9 m; Nässumaa-825, 40.8-41.9 m; Kihnu-526, 86.8-90.1 m; Sakla-GI, 6.2-13.4 m; Kõiguste-833, 3.2-4.8 m; Suurlahe-738, 5.2-5.3 m; Lahetaguse-573, 10.65-14.5 m; Ruhnu-500, 236.40-236.45 m; Kaugatuma-GI, 48.59-48.63 m; Varbla-502, 19.10-22.0 m; Vätta-817, 43.0-43.9 m; Kuressaare-804, 8.0-10.5 m; Kuressaare-GI, 9.23-18.38 m; Pihtla-816, 15.8 m; Tahula-709, 4.7-10.0 m.

Diagnosis. Head scales with cross-shaped or star-shaped ridges; transitional scales rhomboidal with medial and lateral areas of the same width. Trunk scales elongate, with a relatively wide medial and a narrower lateral area; crown posteriorly roundish or pointed, the apex protruding over the base. Pinnal? scales very narrow and keel-shaped; median crown area flat and smooth, or with a notch, or with ridges anteriorly; lateral areas of one to two narrow ridges separated by furrows, all joining posteriorly into an apex. Spur-like process common anteriorly of the base of elongate scales.

Remarks. Gross (1947) first described Loganellia cuneata as Thelodus cuneatus. Later he separated a new type of Logania (now Loganellia) scales which he named L.cruciformis and explained that they might be the head scales of L. cuneata (Gross 1967). Later on thelodont workers, indeed, synonymized L. cruciformis with L. cuneata. Märss (1986) had a broad definition for L. cuneata assigning to this species scales with a cruciform-type of sculpture and those carrying spines and ridges on the crowns. Karatajūtè-Talimaa (1997) divided the scales into two genera, keeping Loganellia for the scales with longitudinal ridges of the crown and establishing a new genus Paralogania for the scales with thornlets and spines on the posterior crown walls. Märss \& Miller (2004) described the scales of L. cuneata in the upper part of the Prridoli, Upper Silurian, from the Gardner's Bank outcrop, $7 \mathrm{~m}$ below the Psammosteus Limestone in the Welsh Borderland. They did not find any rostral scales of this species, only a few transitional scales and numerous trunk scales with crowns that narrow abruptly to the posterior. The scales from the Tahula Beds in our material show traceable transitions from typical cruciform head (or rostral) scales, through scales with a 
flat and smooth crown plate, into elongate posteriorly ridged trunk and pinnal scales. This is the first time that this has been shown clearly for $L$. cuneata.

\section{Description}

Morphology. Head scales (P1. I, figs 1-4) are small, 0.3-0.6 mm long. The crown is smaller than the base. Scales are roundish or crenulated, very often quadrangular. The crown is covered with relatively wide ridges, usually four (Pl. I, fig. 3) to six (Pl. I, fig. 2), but can be as many as eight. The ridges may have finer crenulation ( $\mathrm{Pl}$. I, figs 2, 3). The base is low, with its lower surface being concave (in young scales) to convex (in mature scales). Transitional scales (Pl. I, figs 5-7), 0.5-0.6 mm long, have a wide antero-medial ridge separated from the wide lateral ridges by a notch on both sides. The notches and ridges become longer in more elongate scales (P1. I, fig. 7), the latter also possessing an anterior spur-like process of the base. Trunk scales, $0.60-0.75 \mathrm{~mm}$ long, have at least two varieties: (1) The scales with the median and lateral ridges narrowing to the anterior (P1. I, figs 8-10), and the posterior crown apex protruding posteriorly over the base. The main crown surface is smooth and flat, or inclined to the anterior and posterior (P1. I, fig. 14). The base is with a short spur directed to the anterior and downwards (Pl. I, fig. 13). The majority of the scales in the samples are of that type, and supposedly most of the body of this thelodont was covered with such scales. (2) Multiridged scales (P1. I, figs 12, 16) have a median ridge and two to three lateral ones, all separated by shallow furrows. The ridges and furrows join posteriorly into an apex, with each successive lateral ridge extending farther to the posterior. The base of the scales can have a spur anteriorly (Pl. I, fig. 12). Pinnal scales are of two types. In one type the upper surface of the scale crown is smooth and flat, and lateral ridges occur as fine longitudinal ridgelets beneath the crown plate. The base of these scales lacks an anterior subhorizontal a spur (Pl. I, fig. 11) but it might be directed downwards to the anterior. Such scales may come from the leading edge of a fin. Pinnal scales of the other type (Pl. I, figs 15, 17-21) are strongly elongate, $0.70-1.15 \mathrm{~mm}$ long. These scales also have either a smooth (Pl. I, figs 17, 19, 20) or a finely ridged (Pl. I, fig. 21) median and downstepped lateral area of the crown. As a rule, all strongly elongate scales have a long spur-like process anteriorly (Pl. I, figs 15, 17-21). Sometimes this process carries tubercle-like structures (Pl. I, fig. 17), which can be seen as processes on the base in earlier stages of scale development. Elongate scales have a pulp depression which is wide open (Pl. I, fig. 18) or closed. The pulp canal opening is situated in the posterior corner of the base. The dentine canals are relatively straight, while the dentine tubules are more sinuous (Pl. II, fig. 1). For the detailed histology of these types of scale see Gross (1967, text-fig. 12A-J).

Comparison. Among the numerous Loganellia species only L. cuneata has cruciform and star-like sculpture of the crown of head scales (Gross 1967), while other species have multi-crenulated crowns. Most of the Loganellia species, 
L. cuneata included, have ridged trunk scales, except L. grossi, L. incompta, and L. tuvaensis (see Fredholm 1990; Karatajūtè-Talimaa 1978, 1990), which have a rhombic crown plate with lateral down-stepped rims and an anterior median notch of the crown, which is sometimes absent in L. tuvaensis. However, some L. cuneata fin scales and L. prolata trunk scales have a smooth and flat medial area (Märss et al. 2002). Trunk scales of L. cuneata have fewer ridges than L. einari, L. sibirica, and L. avonia (see Karatajūtè-Talimaa 1978; Märss 1996; Turner 2000) and a less complicated crenulation on the crown margins than $L$. sibirica and $L$. einari, the last one having up to six ridges on both sides. The scales of $L$. cuneata are narrower and ridges smoothly narrowing posteriorly, while some L. almgreeni scales have an abruptly narrowing crown (Blom 1990). The crown of $L$. exilis has three distinct areas nearly of the same width and on the same level, or with lateral areas slightly lower than the median area but rising posteriorly (Märss et al. 2002). In L. prolata and L. almgreeni the medial area is higher and slightly convex, with only one lower lateral area on each side. The ridges or wings on the crown of L. almgreeni scales are wide, forming clear lateral areas. The ridged trunk scales of Loganellia are usually relatively long, but not in L. asiatica. The medial area in L. cuneata, L. prolata, L. exilis, and L. scotica is longer and reaches the posteriormost point of the crown, while in L. sulcata, L. almgreeni, L. avonia, L. matura (see Märss \& Karatajūtè-Talimaa 2002), and L. einari it ends before reaching the posterior point. Loganellia? unispinata has ridged scales, with a short single longitudinal spine on each lateral side of a cuneiform crown (Märss \& Miller 2004); such spines do not occur in L. cuneata. Most Loganellia species have a spur-like process in the anterior of the base of elongated scales, but this has not been recorded in L. einari, L. grossi, L. almgreeni, L. incompta, and L. tuvaensis. The "pockets" or deeper depressions and a deep keel in the lower posterior part of the crown are present in L. sulcata and L. aldridgei, but are absent in all other Loganellia species. Loganellia sibirica and L. asiatica do not have a pulp canal (see Karatajūtè-Talimaa 1978), but it is present in variable width and length in L. cuneata, L. aldridgei, L. avonia, L. almgreeni, L. sulcata, L. prolata, and L. scotica.

\section{Explanation of Plate I}

Figs 1-21. Loganellia cuneata (Gross, 1947). 1-4, head scales; 5-7, transitional scales; 8-10, 12 14,16 , trunk scales; $11,15,17-21$, pinnal scales. 1-12, 16, 17, 19-21, scales in crown view; 14, 15 , scales in lateral view; 13,18 , scales in basal view. Nässumaa- 825 core, depth $41.7 \mathrm{~m}$; Tahula Beds of the Kuressaare Stage, Ludlow, Upper Silurian.

1, GIT 456-60, ×88; 2, GIT 456-59, ×53; 3, GIT 456-61, ×67; 4, GIT 456-62, ×80; 5, GIT 456-64, ×78; 6 , GIT $456-65, \times 80 ; 7$, GIT 456-66, $\times 78 ; 8$, GIT 456-67, $\times 63 ; 9$, GIT 456-77, $\times 66 ; 10$, GIT 456-71, $\times 59 ; 11$, GIT $456-74, \times 58 ; 12$, GIT 456-80, $\times 91 ; 13$, GIT 456-73, $\times 60 ; 14$, GIT 456-78, $\times 75$; 15 , GIT 456-81, $\times 69 ; 16$, GIT 456-76, $\times 57$; 17 , GIT 456-86, $\times 48 ; 18$, GIT 456-85, $\times 57 ; 19$, GIT 456-82, $\times 62 ; 20$, GIT $456-84, \times 52 ; 21$, GIT 456-83, $\times 62$. 
PLATE I

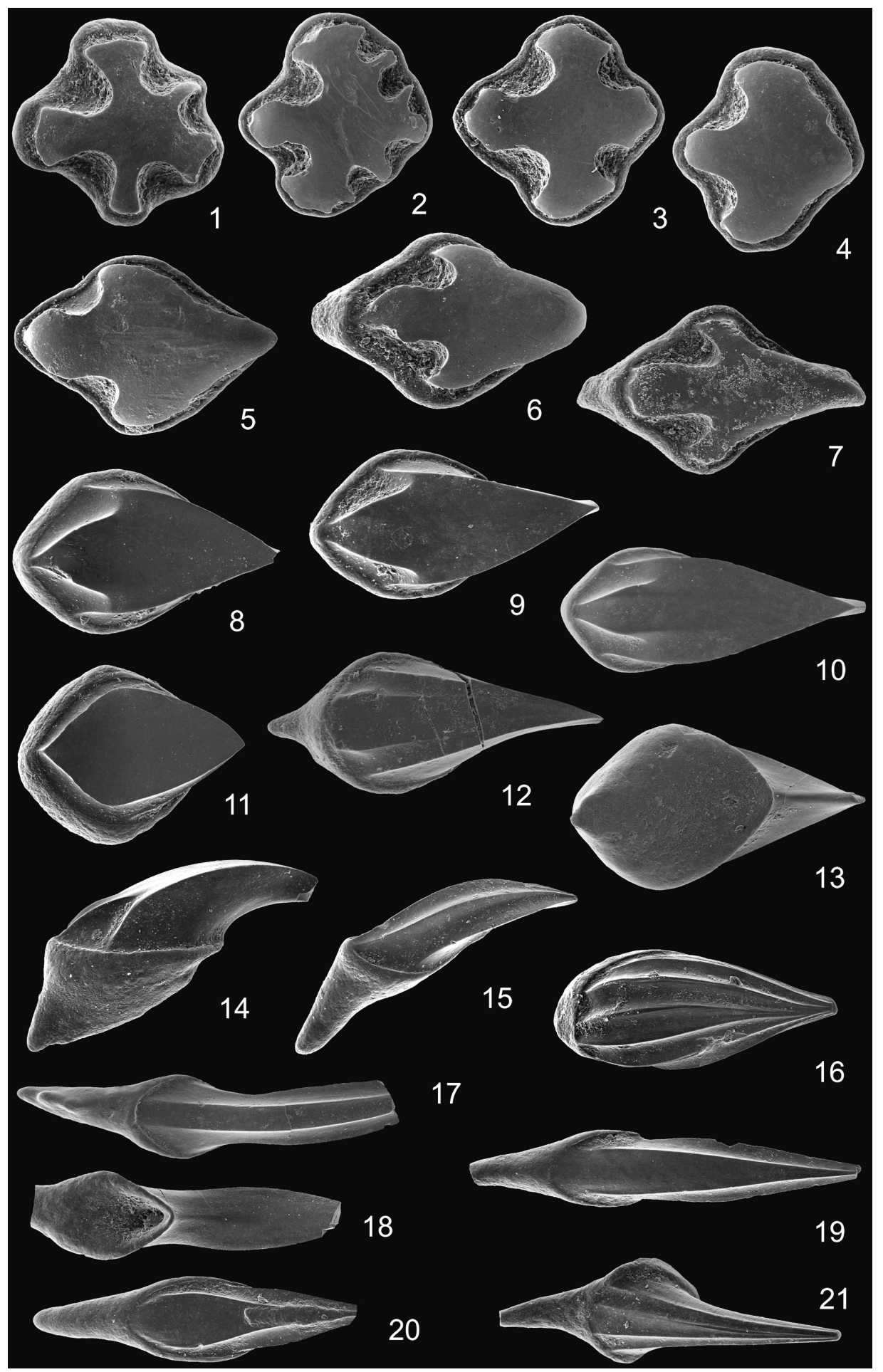


PLATE II
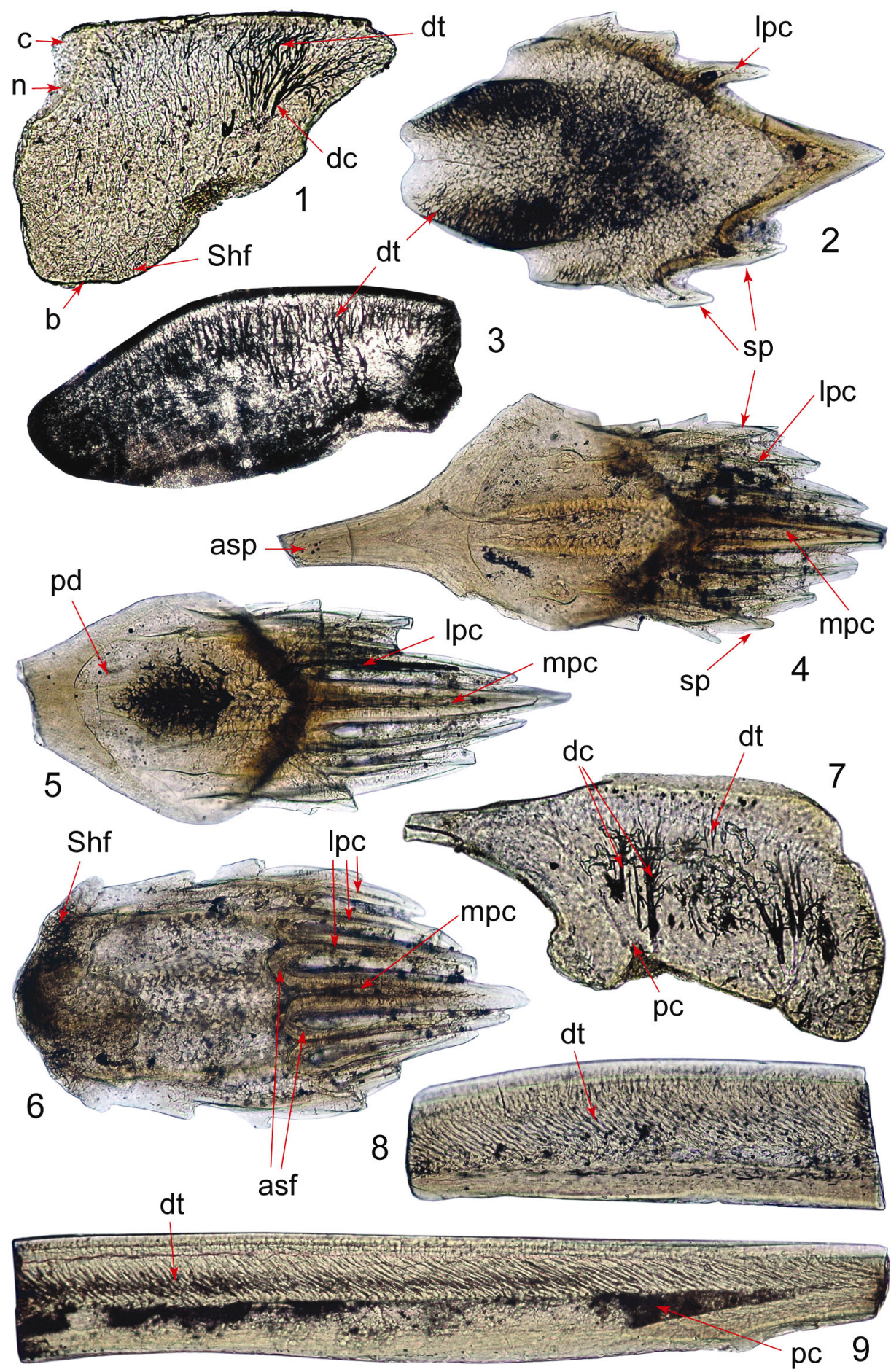
Order SHIELIIFORMES Märss, Wilson \& Thorsteinsson, 2002

Family SHIELIIDAE Märss, Wilson \& Thorsteinsson, 2002

Genus Paralogania Karatajūtè-Talimaa, 1997

Species content. Paralogania borealis (Karatajūtè-Talimaa, 1978); P. consimilis Märss \& Karatajūtè-Talimaa, 2002; P. foliala Blom, 1999; P. kaarmisensis Märss, 2003; P. kachanovi Karatajūtè-Talimaa \& Märss, 2002; P. klubovi Märss \& Karatajūtè-Talimaa, 2002; P. kummerowi (Gross, 1967); P. ludlowiensis (Gross, 1967); P. martinssoni (Gross, 1967); P. menneri Karatajūtè-Talimaa \& Märss, 2002; Paralogania perensae sp. nov.; P. readbayensis Märss et al., 2002; $P$. tarranti Märss \& Miller, 2004; P. wilsoni Karatajūtè-Talimaa \& Märss, 2002.

Paralogania perensae sp. nov.

Plate II, figures 2-4; Plate III, figures 1-24

1986 Logania cuneata (Gross); Märss, pl. 14, figs 4, 6, 7, 9, 10, 12; text-fig. 15: $7-12,21-26$.

Derivation of name. After Mrs Helle Perens, Geological Survey of Estonia, a good colleague who has worked on geological mapping of Saaremaa and has provided samples for microfossil study.

Holotype. Scale GIT 456-6; P1. III, fig. 10.

Type locality and horizon. Laadjala Bridge outcrop on the Kuressaare-Leisi Road, Saaremaa Island, Estonia; Tahula Beds of the Kuressaare Stage, Ludlow, Upper Silurian.

Material. About 100 scales, of which GIT 456-1 to GIT 456-30 were used for SEM images and six scales (GIT 232-98, GIT 232-122, GIT 232-123, GIT 456112, GIT 456-116, and GIT 456-117) for thin sections.

\section{Explanation of Plate II}

Figs 1-9. Histology of the scales. 1, Loganellia cuneata (Gross), vertical longitudinal cross-section. 2-4, Paralogania perensae sp.nov.; 2, 4, horizontal section of transitional and trunk scales, respectively; 3, vertical longitudinal section of the scale. 5, 6, Nethertonodus laadjalaensis sp. nov., horizontal section of the scales. 7, vertical longitudinal section of a palmatilobate scale. 8 , 9, Longodus acicularis gen. et sp. nov., both scale fragments in vertical longitudinal section. 1, 7, Sakla-65 core, depth $13.4 \mathrm{~m}$; 2-6, 8, 9, Kuressaare-804 core, depth 8.0-8.5 m. Saaremaa Island, Estonia; Tahula Beds of the Kuressaare Stage, Ludlow, Upper Silurian.

1, GIT 456-119, ×130; 2, GIT 456-116, ×152; 3, GIT 232-98, ×102; 4, GIT 456-112, ×126;

5 , GIT 456-114, $\times 123 ; 6$, GIT 456-113, $\times 144 ; 7$, GIT 456-118, $\times 151 ; 8$, GIT 456-109, $\times 151$;

9 , GIT 456-110, $\times 167$. Abbreviations: asf, aspidine fold; asp, anterior spur-like process; b, base; c, crown; dc, dentine canal; dt, dentine tubule; lpc, lateral pulp canal; mpc, median pulp canal; pc, pulp canal; pd, pulp depression; Shf, tubules of Sharpey's fibres; n, neck; sp, spine. 
PLATE III

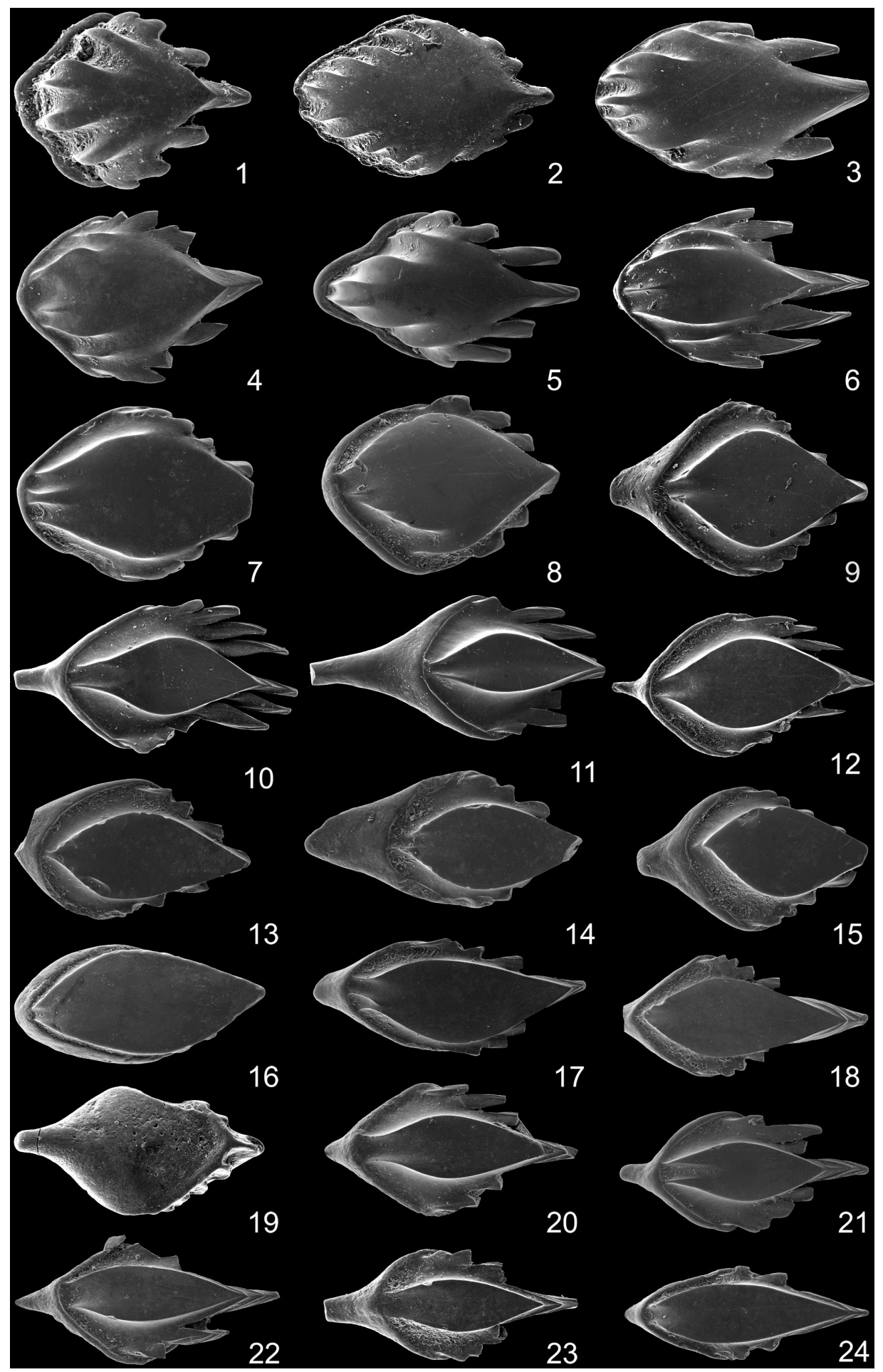


Occurrence. The scales come from the following drill core intervals: OhesaareGI, 92.27-92.31 m; Sutu-605, 21.4-23.2 m; Reo-927, 7.8-9.4 m; Nässumaa-825, 41.3-41.9 m; Kihnu-526, 88.5 m; Sakla-GI, 7.88-13.2 m; Kõiguste-833, 3.2 m; Ruhnu-500, 236.40-236.45 m; Kuressaare-804, 8.0-8.5 m; Varbla-709, 19.10 m; Pihtla-816, $15.8 \mathrm{~m}$; Tahula-709, 7.6-8.4 m.

Diagnosis. Scales flattened and wide; transitional scales richly crenulated anterolaterally and with arched spines posteriorly on the same level as the crown surface; base with long anterior spur; trunk scales with wide crown plate and with three to four postero-lateral arched spines on both sides of the crown wall and one spine beneath the posterior median crown apex; wide furrow separates the crown plate from the base.

\section{Description}

Morphology. The anteriormost head scales are absent in our collection. A set of scales available (Pl. III, fig. 1) were probably positioned more posteriorly of the rostral area. These are relatively short $(0.45 \mathrm{~mm})$, with short ridges and grooves antero-laterally, which run towards the posterior crown corner. Postero-lateral spines are relatively long (partly broken). The spines, three on either side, are directed towards the longitudinal axis of the scales. The crown of the scales is convex. The crown is smaller than the base anteriorly of the scale but extends beyond the base posteriorly.

Crowns of typical transitional scales are oakleaf-shaped, with numerous, up to six short ridges antero-laterally on both sides of the mid-ridge (Pl. III, figs 2, 3). The scales are $0.60-0.85 \mathrm{~mm}$ long. The three to four postero-lateral spines of the crown start from the most lateral furrow and are situated on the same level with it but just slightly lower than the crown main surface. The crown surface is convex. The scales on Pl. III, figs 4-6, can also be treated as transitional, but these are more complicated; their length is $0.6-0.7 \mathrm{~mm}$. The scales are relatively wide, but the ridges on their crowns have sharper crests than the transitional scales. The crown medial surface is flat. The posterior spines are rather long, up to half the length of the main crown. The spines are longitudinally striated, with striae joining along

\section{Explanation of Plate III}

Figs 1-24. Paralogania perensae sp. nov. 1, posteriormost rostral scale; 2, 3, typical transitional scales; 4-8, more specialized transitional scales; 9-15, 17-24, trunk scales; 16 , leading edge scale of a fin. 1-18, 20-24, scales in crown view; 19 , scale in basal view. 1, 4, 6, 10-12, 15-19, 21, Tahula core, depth 7.8 m; 2, 3, 5, 7-9, 13, 14, Laadjala Bridge outcrop; 20, 22-24, Kuressaare-804 core, depth 8.0-8.5 m; Tahula Beds of the Kuressaare Stage, Ludlow, Upper Silurian.

1, GIT 456-1, $\times 78 ; 2$, GIT 456-10, $\times 46 ; 3$, GIT 456-4, $\times 67 ; 4$, GIT 456-25, $\times 60 ; 5$, GIT 456-3, $\times 60$; 6 , GIT 456-2, $\times 57$; 7, GIT 456-14, $\times 55$; 8, GIT 456-12, $\times 61$; 9, GIT 456-13, $\times 46$; 10, holotype GIT 456-6, $\times 38$; 11, GIT 456-7, ×39; 12, GIT 456-21, ×41; 13, GIT 456-15, ×47; 14, GIT 456-17, ×48; 15 , GIT 456-16, $\times 48 ; 16$, GIT 456-18, $\times 53$; 17, GIT 456-24, $\times 44 ; 18$, GIT 456-22, $\times 37$; 19, GIT 456-20, $\times 39 ; 20$, GIT 456-26, $\times 55 ; 21$, GIT 456-5, $\times 41 ; 22$, GIT 456-27, $\times 57 ; 23$, GIT 456-28, $\times 58$; 24 , GIT $456-29, \times 55$. 
the midline of the spines. Scales with smooth crown margins but with three ridges instead of one notch antero-medially (Pl. III, fig. 7) are also included in the present definition of transitional scales. Similarly, oval scales having smoothly rounded corners, gentle ridges anteriorly of the crown plate, a median notch, and a deep notch on both sides (Pl. III, fig. 8) are also considered transitional. Three to four postero-lateral spines of such scales are situated distinctly lower than the crown surface. The length of the scales is $0.60-0.65 \mathrm{~mm}$.

Trunk scales, 0.60-1.12 mm long, form the majority of the scales of this taxon in samples (Pl. III, figs 9-15, 17-24). The crown plate is flat, smooth, rhomboidal, with smoothly rounded lateral corners (Pl. III, figs 9-15). Anteriorly there can be a notch, rarely two (Pl. III, fig. 17), or it is absent (Pl. III, figs 15, 18). The base is always wider than the crown. A wide groove occurs between the base and the crown plate, continuing backwards above the spines behind the lateral corners of the crown (Pl. III, figs 9-15, 20-23). Three to five arch-like lateral spines may be rather long (Pl. III, figs 10, 11). A postero-median spine is situated beneath the posterior corner of the crown. Spines are longitudinally striated, with striae joining along the midline (Pl. III, figs 10-12). The base is distinct anteriorly (Pl. III, figs 10-12, 20-24). All scales have a spur-like projection anteriorly varying in length and width.

The posteriormost part of the trunk and fins were covered with narrow and elongate scales (Pl. III, fig. 24). The anterior part of fins (P1. III, fig. 16) carried more compact scales having a smooth and flat crown plate with an anterior notch and a relatively narrow base without anterior spur.

Histology. The microstructure of the scales is similar to that of Paralogania. Main median and two to three lateral pulp canals enter into the posterior spines and extend nearly to the posterior end of the spine (Pl. II, figs 2, 4). In the transitional scales the dentine canal openings are placed evenly in the pulp depression (Pl. II, fig. 2). Both the dentine canals and the dentine tubules in the upper part of the crown, are relatively straight (Pl. II, fig. 3).

Comparison. The new species is most similar to P. wilsoni (see KaratajūtèTalimaa \& Märss 2002) as trunk scales are wide and flattened and have wide lateral portions of the crown. Differences occur in the sculpture of transitional scales and the shape of the base of trunk scales: transitional scales of $P$. perensae sp. nov. are richly crenulated antero-laterally, while those of $P$. wilsoni have modest crenulation; the anterior spur of the base always present in $P$. perensae sp. nov. is long, while in $P$. wilsoni it is short. Many species of the genus, such as $P$. perensae sp. nov., $P$. martinssoni, $P$. tarranti, and $P$. kummerowi, have a series of spines forming a row extending up to the posterior crown apex (Gross 1967; Märss \& Miller 2004). The spines are arched in $P$. perensae sp. nov. but almost straight in other species. Paralogania perensae sp. nov. differs from P. tarranti and $P$. kummerowi in having a more restricted range (3-4) of posterolateral spines than $P$. tarranti (3-5) and $P$. kummerowi (5-8). The range in the number of spines in $P$. perensae sp. nov. and $P$. martinssoni is the same but the scales of 
P. perensae sp. nov. are much larger. Paralogania perensae sp. nov. differs from $P$. kaarmisensis and $P$. readbayensis in having the posterolateral spines along the entire crown margin, while in $P$. kaarmisensis and $P$. readbayensis they are situated more to the anterior (see Märss et al. 2002; Märss 2003). The slanting longitudinal ridge laterally above the row of spines of the crown is absent in P. perensae sp. nov. but present in P. ludlowiensis, P. kaarmisensis, and P. consimilis (see Gross 1967; Märss \& Karatajūtè-Talimaa 2002; Märss 2003). Paralogania borealis may also carry a slanting ridge above the spines. It has a pair of low and narrow ridgelets or a row of 4-8 short spinelets on the posterolateral crown walls (Karatajūtè-Talimaa 1978). Paralogania ludlowiensis scales have a double-spine beneath the posterior crown apex, while our new species has just one spine (Gross 1967; Miller \& Märss 1999). Rhombic scales of P. foliala have a much more complicated sculpture; a large flat crown with a triangular medial area carries one short, deep and steep antero-medial notch, and large lateral "wings" form at least three posteriorly pointing spines at the same level as the medial spine (Blom 1999). A similar steep and deep medial notch and lateral "wings" have not been observed in any other Paralogania species except P. klubovi, whose scales have two to three lateral spinelets, which may occur as flat, short, and widened winglets. Paralogania menneri differs from $P$. perensae sp. nov. in having transitional? scales with a wider anterior half, notches anterolaterally of the crown, and a narrow and relatively long posterior "tail" or spurlike projection (see Karatajūtè-Talimaa \& Märss 2002). Paralogania kachanovi has more monolithic scales than P. perensae sp. nov. and as many spines (up to eight) as $P$. kummerowi.

Genus Nethertonodus Märss \& Miller, 2004

Type species. Nethertonodus prodigialis Märss \& Miller, 2004.

Species content. Nethertonodus prodigialis Märss \& Miller, 2004; N. laadjalaensis sp. nov.

Diagnosis. Small to medium scales, $0.3-1.13 \mathrm{~mm}$ long. Short, upwardly directed spines or spine clusters with roundish cross-section at anterior ends of crown ridges of most scale types. Trunk scales with a pair of medial ridges with a longitudinal furrow, and with up to three lateral ridges on both sides also separated by furrows. Neck as a shallow furrow. Trunk scales have up to seven pulp canal openings, one of main canal and six of lateral canals; dentine canal openings placed evenly in the pulp depression or in a longitudinally dispersed row (emended from Märss \& Miller 2004).

Distribution. Upper Ludlow-Lower Pridoli of Britain (top of the Whitcliffe Formation and the basal Downton Castle Sandstone Formation) and Baltic (Tahula Beds of the Kuressaare Stage). 
Nethertonodus laadjalaensis sp. nov.

Plate II, figures 5, 6; Plate IV, figures 1-16, 26

Derivation of name. After the Laadjala Bridge outcrop where the taxon was first identified.

Holotype. Scale GIT 456-31, P1. IV, fig. 2.

Type locality and horizon. Laadjala Bridge outcrop on the Kuressaare-Leisi Road, Saaremaa Island, Estonia; Tahula Beds of the Kuressaare Stage, Ludlow, Upper Silurian.

Material. About 50 trunk scales, of which those numbered as GIT 456-31 to GIT 456-58 were used for SEM images and two scales (GIT 456-113 and GIT 456-114) were used for thin section analysis. Head scales and transitional scales were not found in the available material.

Occurrence. Scales come from the Laadjala outcrop and the following drill core intervals: Ohesaare-GI, 90.75-91.00 m; Sutu-605, 23.0-23.2 m; Nässumaa-825, 41.7-41.9 m, Kuressaare-804, 8.0-8.5 m.

Diagnosis. Trunk scales elongate, trumpet-like with roundish cross-section; crown sculpture ridges rise arch-like from the furrow between the crown and base; paired medial and one to three lateral longitudinal crown ridges carry a spine anteriorly directed upwards and backwards; ridges supported by a longitudinal keel on the lower side. Base always with a spur-like process anteriorly; pulp depression deep and flared towards opening. One main and up to three lateral pulp canals on both sides of trunk scales; fine dentine canal openings evenly distributed in pulp depression in transitional scales.

\section{Explanation of Plate IV}

Figs 1-16, 26. Nethertonodus laadjalaensis sp. nov. trunk scales. 1-8, 10, 11, 13-16, scales in crown view; 7,8 , scales in lateral view; 9,12 , scales in basal view; 26 , ultrasculpture of the crown surface.

Figs 17-25, 27. Palmatilobate scales of Paralogania? sp. 17, 18, 20, 24, 25, scales in crown view; 19,22 , scales in basal view; 21,23 , scales in oblique crown view; 27 , ultrasculpture of the crown surface.

Laadjala Bridge outcrop, Saaremaa Island, Estonia; Tahula Beds of the Kuressaare Stage, Ludlow, Upper Silurian.

$1=26$, GIT 456-39, $\times 47$ (for 1); 2, holotype GIT 456-31, $\times 47$; 3, GIT 456-32, ×44; 4, GIT 456-41, $\times 53$; 5 , GIT 456-50, ×59; 6, GIT 456-48, ×51; 7, GIT 456-46, $\times 78 ; 8$, GIT 456-40, ×70; 9, GIT 456-38, $\times 44 ; 10$, GIT 456-37, $\times 44 ; 11$, GIT 456-47, $\times 67 ; 12$, GIT 456-49, ×48; 13 , GIT 456-33, $\times 39$; 14, GIT 456-36, $\times 47$; 15, GIT 456-35, $\times 38 ; 16$, GIT 456-42, $\times 44 ; 17$, GIT 456-45, $\times 47 ; 18$, GIT 456-51, $\times 90 ; 19$, GIT 456-53, $\times 89 ; 20$, GIT 456-55, $\times 80 ; 21$, GIT 456-52, $\times 95 ; 22$, GIT 456-44, $\times 75$; $23=27$, GIT 456-57, $\times 89$ (for 23); 24, GIT 456-54, $\times 65$; 25, GIT 456-58, $\times 58$. 
PLATE IV

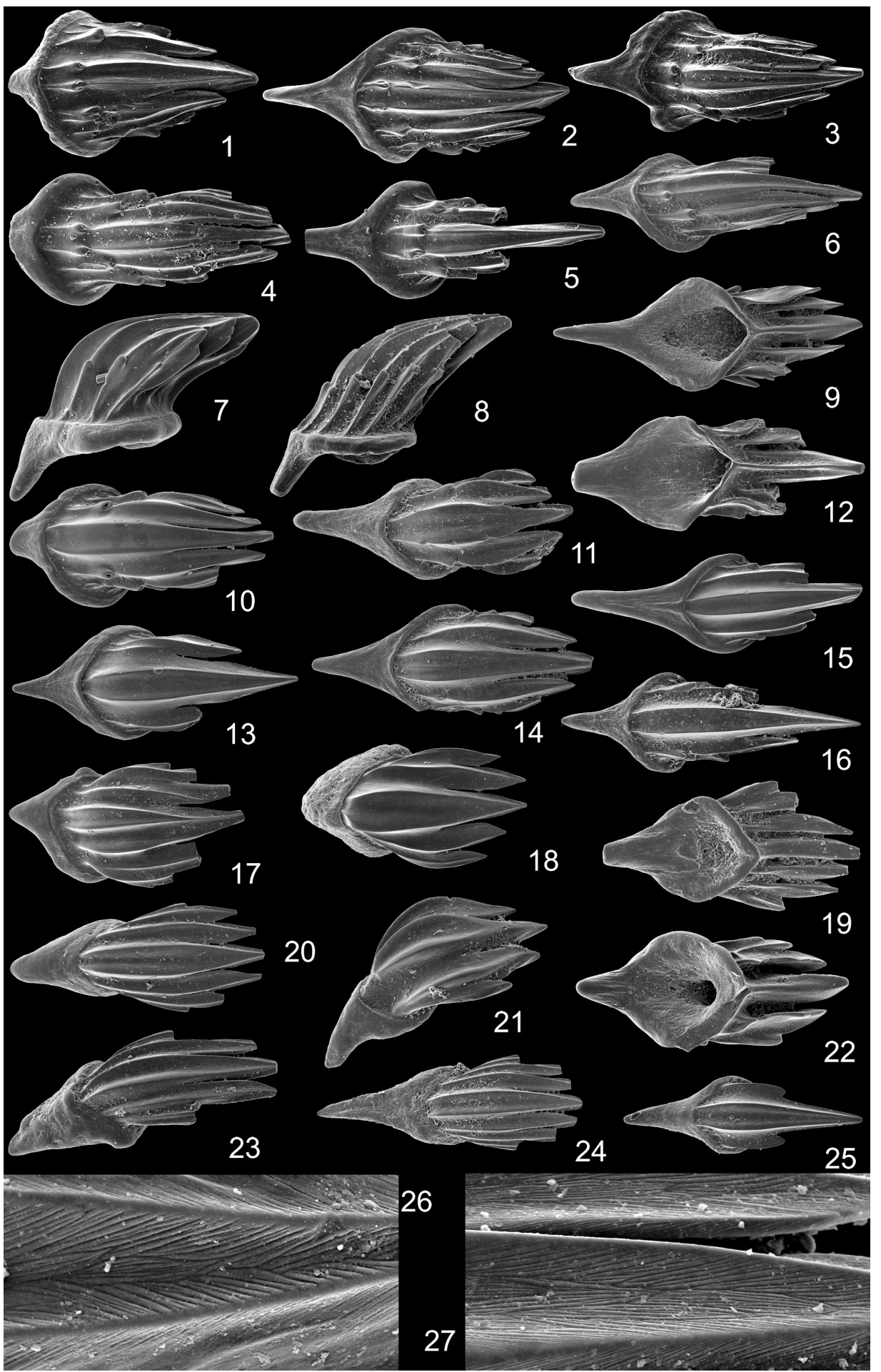




\section{Description}

Morphology. Trunk scales are elongate (length $0.60-1.13 \mathrm{~mm}$ ). Ridges and grooves rise arch-like from the furrow between the crown and the base (Pl. IV, figs 1-16). The crown sculpture consists of paired medial and one to three strong lateral longitudinal ridges (sometimes with one additional small ridge, Pl. IV, fig. 1), which run subparallel posteriorwards where each of them terminates with an apex. The median ridge is the longest, with more lateral ridges becoming shorter towards the margin. The crowns have a broken short spine in the anterior half of ridges. In some of the scales each ridge has such a spine (Pl. IV, figs $1-6,8)$, but in others the medial ridges lack spines (Pl. IV, figs 10, 11), or only the most lateral ridge has it (Pl. IV, figs 13-16). A dentine canal can be seen in the centre of such broken spines. The ridges have a longitudinal keel on the lower side (Pl. IV, figs 7-9, 12). The base is always spur-like and is directed to the anterior (Pl. IV, figs 1-6, 9-16) or to the anterior and downwards (Pl. IV, figs 7, 8). The anterior end of the base is often pointed (Pl. IV, figs 2, 3, 6, 9, 13-16). The deep and trumpet-like pulp depression is situated in the posterior corner of the lower surface of the base (Pl. IV, figs 9, 12).

Ultrasculpture. The ultrasculpture of the crown is of longitudinal striation rising to the sculpture ridges; in the grooves it has sets of shorter ridges (Pl. IV, fig. 26).

Histology. The number of side pulp canals depends on the number of crown ridges - up to three on either side of the main medial one (Pl. II, figs 5, 6). The posterior spines are joined together with a continuous aspidine fold (Pl. II, fig. 6). Dentine canals are fine. Their openings are situated evenly in the pulp depression of transitional scales but forming slightly dispersed rows in more posterior scales (Pl. II, fig. 6). Dentine tubules in the spines are very fine.

Comparison. Trunk scales of $N$. laadjalaensis sp. nov. are of medium size, $0.60-1.13 \mathrm{~mm}$ long, while in $N$. prodigialis they are $0.3-0.6 \mathrm{~mm}$ long. Short, upward directed spines are single in $N$. laadjalaensis sp. nov. and do not occur in clusters as in $N$. prodigialis. Both species have spines of roundish cross-section anteriorly on the crown of trunk scales at the anterior ends of crown ridges. Trunk scales of $N$. laadjalaensis sp. nov. may lack spines at the end of medial ridges. In trunk scales of $N$. prodigialis the postero-lateral spines beneath the lateralmost ridge are directed upwards and backwards in a complicated overlapping arrangement, often with double or triple ends (Märss \& Miller 2004, pl. 5, figs 3, 4, 20), while in $N$. laadjalaensis sp. nov. the spines are more parallel.

Palmatilobate scales of Paralogania? sp.

Plate II, figure 7; Plate IV, figures 17-25, 27

1986 Logania cuneata (Gross); Märss, pl. 13, figs 5, 7, 10; pl. 15, figs 1-4; text-fig. 15: 27-29.

Material and occurrence. Relatively short and multi-ridged (palmatilobate or palmatiform) scales are found (Pl. IV, figs 17-25, 27) in the Tahula Beds of the 
Kuressaare Stage in many drill cores (Sõrve-514, 140.2-144.4 m; Ohesaare-GI, 92.60-93.40 m; Sakla-GI, 10.25-13.40 m; Kõiguste-833, 3.2-4.4 m; Kuressaare804, 8.0-8.5 m; Tahula-709, 7.6-7.8 m; Sutu-605, 23.0-23.7 m; Reo-927, 8.812.9 m; Nässumaa-825, 41.3-41.9 m; Kihnu-526, 88.5-88.9 m). Such scales occur mainly together with Loganellia cuneata (Gross).

Description. The scales are $0.4-0.6 \mathrm{~mm}$ long, with ridges each ending with a posterior apex. The total number of the ridges is usually five, the median one being the longest; the ridges are supported by a keel on the lower surface (Pl. IV, figs 19, 22). Their pulp canal is situated in the posterior third of the base, dentine canals are relatively wide and straight and dentine tubules irregularly sinuous (Pl. II, fig. 7).

Remarks. The scales are very different from those of L. cuneata in having five apices posteriorly and a keel on the lower surface of the crown, while the crown of L. cuneata ends with one apex. In having several apices of the crown, palmatilobate scales are similar to $N$. laadjalaensis sp. nov. and some Paralogania species. Nethertonodus laadjalaensis sp. nov. has upwardly directed fine spines to the anterior of the ridges which are not present in Paralogania? sp. In the latter the spur-like process of the base of the scales is shorter, often directed downwards (P1. IV, figs 18, 21, 23). The medial ridges of the scales of $N$. laadjalaensis sp. nov. can also be without anterior spines, thus the complete absence of such spines on the crown ridges may represent a scale variety of $N$. laadjalaensis sp. nov. However, scales of $N$. laadjalaensis sp. nov. are relatively rare, while palmatilobate scales occur in many drill core samples.

The ultrasculpture of Paralogania is of simple longitudinal striation, that of palmatilobate scales of fine striation on the ridges and crosscutting striae in the grooves, in this respect resembling $N$. laadjalaensis sp. nov. (no ultrasculpture has been found on loganiid scales). Possibly palmatilobate scales belong to a new species of Paralogania with a modified ultrasculpture of the crown.

INCERTI ORDINIS

Family LONGODIDAE fam. nov.

Type genus. Longodus gen. nov.

Diagnosis. Squamation of thelodont type; contiguous scales longitudinally strongly stretched, the width:length ratio up to $1: 11$. Ultrasculpture of transverse lamellae, which cross between the ridges and bend backwards towards the crests of the ridges, giving the surface a rippled appearance. Pulp canal present; upper crown with vertical dentine tubules up to $1 / 3$ of the total scale thickness.

Remarks. Representatives of this taxon (Longodus acicularis gen. et sp. nov.) differ from other known thelodonts in morphology, sculpture, microstructure, and 
ultrasculpture of trunk scales. They have needle-shaped scales, while the others have variously rounded, rhomboidal or elongate wedge-shaped scales; Sandiviidiformes, Loganelliiformes, several Thelodontiformes, and Phlebolepidiformes have ridged sculpture of the crown; Shieliiformes has spines posterolaterally of it. The scales of the taxon under study are very fine as well as those of Furcacaudiformes but differ in the configuration of the crown. The former are strongly elongate and very narrow, while the latter are rhomboidal or rhombic. The largest are the scales of Phlebolepidiformes. The ultrasculpture of the representatives of this family and Furcacaudiformes is similar as they both have transverse lamellae. Representatives of the family Longodidae have lamellae of rather uniform length, Furcacaudiformes, however, also has smaller polygons combined with lamellae. Representatives of other orders differ in ultrasculpture of the scale crown. Specimens of Oeseliidae Märss have a very fine network-like pattern, the polygons being of very irregular shape, often curvy or kidney-shaped, and separated by fine grooves. Thelodontiformes, Shieliiformes, and Phlebolepidiformes have fine longitudinal striation, while scales of Sandiviidiformes and Loganelliiformes have not revealed any ultrasculpture so far. The pulp canal is absent in Sandiviidiformes and some Loganelliiformes, but is present in all other orders (Shieliiformes has one main and up to eight side canals corresponding to the side ridges of the crown; in Thelodontiformes the pulp canal occurs occasionally). Wide dentine canals are distributed evenly in Phlebolepidiformes, while Sandiviidiformes has fine and narrow dentine canals. In Longodus acicularis gen. et sp. nov. the dentine tubules are wavy, as are dentine tubules in ridged scales of Thelodus laevis and Talivalia elongata. One single deep pulp cavity is present in Thelodontiformes, while Longodus acicularis gen. et sp. nov. has a long open pulp depression or an elongate slit-like pulp opening which posteriorly terminates with a long pulp canal.

The scales of described Longodidae fam. nov. (Longodus acicularis gen. et sp. nov.) resemble exoskeletal elements of some heterostracans. Heterostraci? gen. et sp. 1 and Heterostraci gen. et sp. 2 from Baillie-Hamilton Island, Canadian Arctic (Märss et al. 1998b, fig. 1) have single ridges (odontodes), but they also have compound scales with several ridges which are absent in Longodus acicularis gen. et sp. nov. All heterostracan scale ribs, mentioned above, are several times wider than those of the scales of Longodus acicularis gen. et sp. nov. The ultrasculpture of Longodus is of lamellae in the sculpture grooves which rise to the posterior; they are short and join on the sculpture ridges. In pteraspidid heterostracans, transverse lamellae occur together with irregular polygons and lacriform fields situated at the serrated marginal extremities. The family Longodidae certainly belongs to the subclass Thelodonti as its squamation is built of separate dermal scales with a crown, neck, and base. The crown consists of dentine covered by enameloid, the base is of acellular aspidin, and the squamation is built of different scale types. 
Genus Longodus gen. nov.

Derivation of name. Latin word longus, long, and Greek word odus, tooth, meaning long tooth (a term used for thelodont scales).

Type species. Longodus acicularis gen. et sp. nov.

Diagnosis. As for type species.

Distribution. As for type species.

Longodus acicularis gen. et sp. nov.

Plate V, figures $1-20$

Derivation of name. Latin acicularis, needle-shaped, referring to the unusually elongate and narrow scales with pointed ends.

Holotype. Scale GIT 456-96; Pl. V, fig. 11.

Type locality and horizon. Depth $8.0-8.5 \mathrm{~m}$, Kuressaare-804 core, Saaremaa Island, Estonia; Tahula Beds of the Kuressaare Stage, Upper Ludlow, Upper Silurian.

Material. 60 specimens, complete scales and broken fragments, of which GIT 456-87 to GIT 456-106 were used for SEM images and five (GIT 456-107 to GIT 456-111) for thin sections.

Occurrence. Kuressaare-804 core, depth 8.0-8.5 m, and Nässumaa-825 core, depth 41.3 m, Saaremaa Island, Estonia; Tahula Beds of the Kuressaare Stage, Upper Ludlow, Upper Silurian.

Diagnosis. Narrow and relatively long $(0.5-1.0 \mathrm{~mm})$ scales with width:length ratio up to $1: 11$. Almond-shaped head? scales with smooth, slightly convex crown surface; elongate transitional? scales ridged along the margins, base as a wall around the crown with short spur curved downwards anteriorly; strongly elongate trunk? scales have long ridges which converge posteriorly. Pulp opening of two types, as open elongate depression with regularly distributed dentine canal openings, or as a narrow slit. Pulp canal present; it can be long. Dentine tubules fine, sinuous in the lower $2 / 3$ of the crown, and vertical in the upper $1 / 3$ of the crown. The ultrasculpture of short lamellae in the sculpture grooves pointed to the posterior and joining on the sculpture ridges; lamellae of uniform length, with maximum length up to $5 \mu \mathrm{m}$.

\section{Description}

Morphology. As such delicate, very fine, and narrow needle-shaped scales were found for the first time, an attempt to attribute any scale variety to any part of the body must be taken as a presumption. Head? scales are nearly oval, almond- 
PLATE V

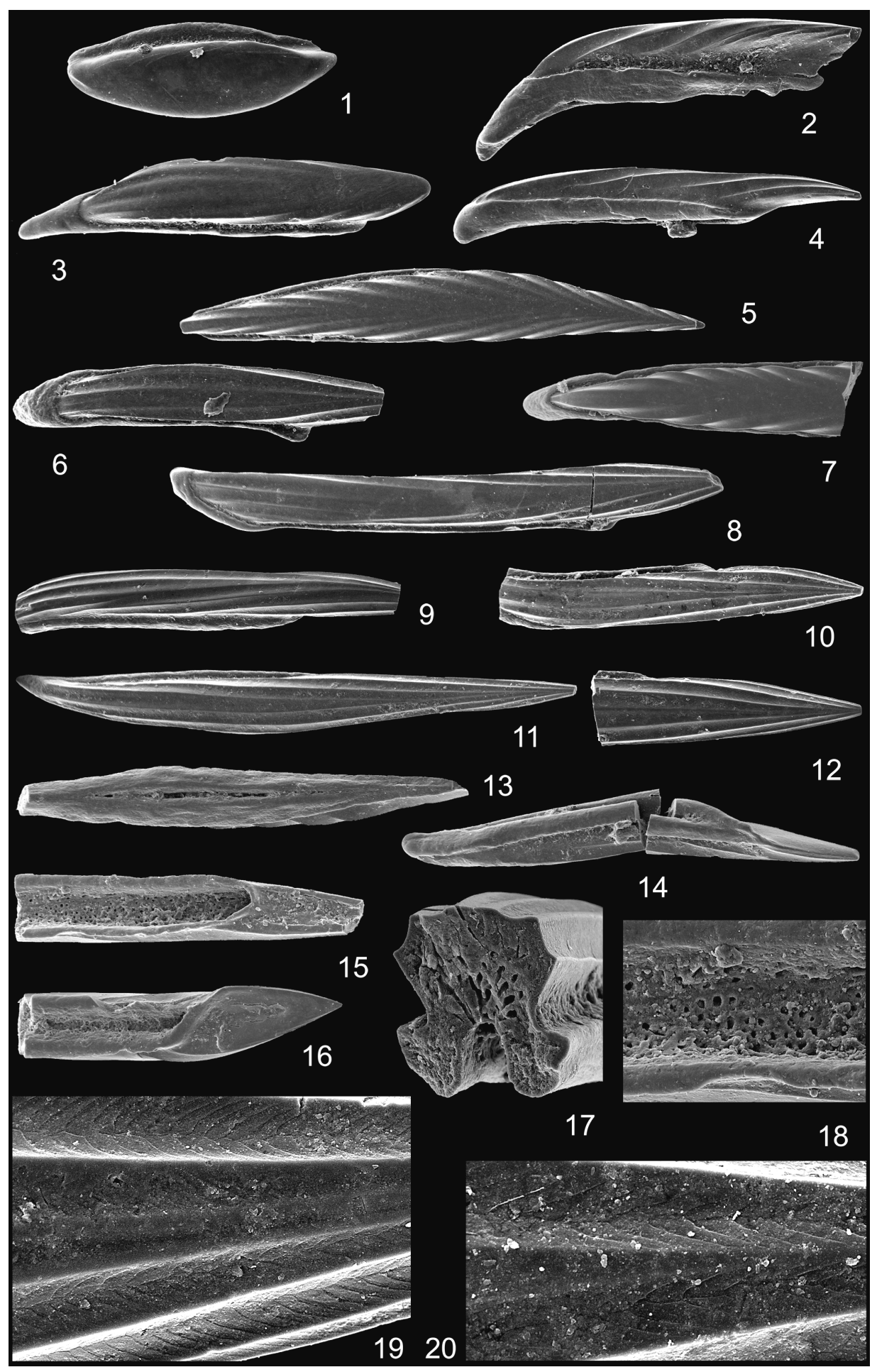


shaped, with smooth, slightly convex crown surface (Pl. V, fig. 1; the length of this scale is $0.5 \mathrm{~mm}$ ). The fin? scales coming from the anterior of the fins are illustrated on Pl. V, figs 2-4, 6, 13, 14. They are relatively short and strong, with gentle ridges laterally, which rise towards the posterior crown apex. The length of the scales is $0.65-0.90 \mathrm{~mm}$. Sometimes pearl-like rootlets grow out of the base (Pl. V, fig. 2). Transitional? scales are strongly elongate and ridged along the margins; their base is like a wall around the crown with short spur curved downwards anteriorly ( $\mathrm{Pl}$. V, figs 5, 7). The length of the specimen on $\mathrm{Pl}$. V, fig. 5 is $1.0 \mathrm{~mm}$. Trunk? scales (Pl. V, figs 8-12, 15-18) are strongly elongate (length of complete scales is $1.0-1.15 \mathrm{~mm}$ ); their width:length ratio is $1: 7$ to $1: 11$. In this type of scales, long ridges converge in the posterior part of the crown. The posterior end of the lower surface of the crown is smooth, with a wall around the base $(\mathrm{Pl}$. V, figs 15,16$)$. The scales are of contiguous type except that the posteriormost end overlaps the scale to the posterior; the wall marks the overlapping area ( $\mathrm{Pl}$. V, figs 15,16$)$. The neck in all varieties is as a shallow narrow furrow. Pulp opening of transitional? and trunk? scales is of two types: (1) open depression in juvenile scales with regularly spaced dentine canal openings (Pl. V, figs 15, 18), and (2) narrow slit in mature scales (Pl. V, fig. 13).

Ultrasculpture. Short, regular lamellae in the sculpture grooves rise to the posterior, join on the sculpture ridges and point to the posterior (Pl. V, figs 19, 20); the ultrasculpture has a wavy appearance on the crown. Lamellae are of uniform width, which in the sculpture grooves is ca. $5 \mu \mathrm{m}$.

Histology. Fine, sinuous dentine tubules extend from the pulp depression and pulp canal to the anterior; higher in the crown they turn vertically towards the crown surface (Pl. II, figs 8,9$)$. The upper layer of the finest and straightest dentine tubules is relatively thick, about one-third of the crown thickness (Pl. V, fig. 17). The dentine tubules are distributed evenly throughout the crown length. The pulp canal is situated to the posterior of the crown.

\section{Explanation of Plate V}

Figs 1-20. Longodus acicularis gen. et sp. nov. 1, head? scale; 2-4, 6, 13, 14, more robust (fin?) scales; 5,7 , transitional? scales; $8-12,15-18$, trunk? scales; 17 , microstructure of the scale in cross-section; 18 (detail of fig. 15), openings of dentine canals in the pulp depression; 19 , 20 , ultrasculpture of the crown surface (19, detail of fig. 12; 20, detail of fig. 6). 1, 3, 5-12, scales in crown view; 2, 4, 14, scales in lateral view; 15, 16, scales in basal view. Kuressaare-804 core, depth 8.0-8.5 m, Saaremaa Island, Estonia; Tahula Beds of the Kuressaare Stage, Ludlow, Upper Silurian. 1, GIT 456-87, $\times 80 ; 2$, GIT 456-106, $\times 86 ; 3$, GIT 456-97, $\times 82 ; 4$, GIT 456-89, $\times 67 ; 5$, GIT 456-100, $\times 77 ; 6=20$, GIT 456-99, $\times 85$ (for 6); 7, GIT 456-91, $\times 75 ; 8$, GIT 456-95, $\times 70 ; 9$, GIT 456-103, $\times 63 ; 10$, GIT 456-98, $\times 68 ; 11$, holotype GIT 456-96, $\times 85 ; 12=19$, GIT 456-92, $\times 80$ (for 12); 13 , GIT 456-90, $\times 67 ; 14$, GIT 456-88, ×79; $15=18$, GIT 456-104, $\times 102$ (for 15); 16, GIT 456-93, ×85; 17, GIT 456-105. 


\section{SUMMARY}

The species Loganellia cuneata (Gross) was described, and Paralogania perensae sp. nov. and Nethertonodus laadjalaensis sp. nov., as well as Longodus acicularis gen. et sp. nov. from the family Longodidae fam. nov., were established. These taxa come from the basal beds of the Kuressaare Stage of Estonia. On the basis of a completely different shape of the scales, which is somewhat similar to heterostracan ribs, and the ultrasculpture pattern of the crown resembling both the furcacaudid and pteraspidid heterostracan ultrasculpture, the family Longodidae was established in an unknown (unnamed) order in the subclass Thelodonti. Being very different from other Thelodonti, Longodus gen. et sp. nov. is important for the taxonomic and phylogenetic study of this subclass. In the future it may be justified to establish a new order for this taxon.

Based on the genus Nethertonodus Märss \& Miller, some rough correlations are possible between the Baltic region and Britain, with $N$. prodigialis coming from the Upper Ludlow-Lower Pridoli of Britain (top of the Whitcliffe Formation and the basal Downton Castle Sandstone Formation) and N. laadjalaensis from the Upper Ludlow of the Baltic (Tahula Beds of the Kuressaare Stage).

\section{ACKNOWLEDGEMENTS}

The study was carried out in the Institute of Geology at Tallinn University of Technology (IGTUT) and was supported by governmental target funding (project No. 0331760s01) and the Estonian Science Foundation (grants 5726 and 5920). Helle Perens and Elmar Kala, Geological Survey of Estonia, have been long-term collaborators with us in the geological research of Estonia and have supplied us with the samples from many drill cores. Heldur Nestor, IGTUT, consulted on the aspects of sedimentation during the Ludlow Age. Valdek Mikli took SEM images of the scales and Gennadi Baranov prepared the plates. Two referees, H. Blom, Uppsala, and G. Miller, London, made valuable comments on the manuscript. The help of all people and institutions mentioned above is gratefully acknowledged.

\section{REFERENCES}

Berg, L. S. 1937. A classification of fish-like vertebrates. Bull. Acad. Sci. USSR. Classe des sci. math. natur., 1937, 1277-1279.

Blom, H. 1999. Vertebrate remains from Upper Silurian-Lower Devonian beds of Hall Land, North Greenland. Bull. Geol. Greenland Surv., 182, 1-80.

Cope, E. D. 1889. Synopsis of the families of Vertebrata. Amer. Naturalist, 23, 849-887.

Fredholm, D. 1990. Agnathan vertebrates in the Lower Silurian of Gotland, Sweden. Geol. För. Stockholm Förhandl., 112, 61-84.

Gross, W. 1947. Die Agnathen und Acanthodier der Obersilurischen Beyrichienkalks. Palaeontographica, 96, Abt. A, 91-161.

Gross, W. 1967. Über Thelodontier-Schuppen. Palaeontographica, 127, Abt. A, 1-67. 
Karatajūtè-Talimaa, V. N. 1978. Telodonty silura i devona SSSR i Spitsbergena. Mokslas, Vilnius (in Russian).

Karatajūtè-Talimaa, V. N. 1990. Vertebrates. In Silur i devon Yugo-Vostoka Zapadno-Sibirskoj plity (Kul'kov, N. P. \& Tubatolov, V. N., eds), pp. 59-63. Nauka, Moscow (in Russian).

Karatajūte-Talimaa, V. 1997. Taxonomy of loganiid thelodonts. Modern Geol., 21, 1-15.

Karatajūtè-Talimaa, V. \& Märss, T. 1999. Thelodonti. Biostratigraphical analysis. In Silurian and Devonian Stratigraphy of Severnaya Zemlya Archipelago (Matukhin, R. G. \& Menner, V. V., eds), pp. 121-127. SNIIGGIMS, Novosibirsk (in Russian).

Karatajūtė-Talimaa, V. \& Märss, T. 2002. Upper Silurian thelodonts from Severnaya Zemlya Archipelago (Russia). Geodiversitas, 24, 405-443.

Karatajūtè-Talimaa, V. \& Märss, T. 2004. Subclass Thelodonti. In Fossil Vertebrates of Russia and Adjacent Countries. Agnathans and Early Fishes (Novitskaya, L. I. \& Afanassieva, O. B., eds), pp. 12-68. GEOS, Moscow (in Russian).

Kiaer, J. 1932. New coelolepids from the upper Silurian of Oesel (Estonia). Publ. Geol. Inst. Tartu Univ., 27, 1-8.

Märss, T. 1986. Silurian vertebrates of Estonia and West Latvia. Fossilia Baltica, 1. Valgus, Tallinn (in Russian with extended English summary).

Märss, T. 1992. Vertebrate history in the Late Silurian. Proc. Estonian Acad. Sci. Geol., 41, 205-214.

Märss, T. 1996. Loganellia (Thelodonti, Agnatha) from the Jaagarahu Stage, Wenlock, Estonia. Proc. Estonian Acad. Sci. Geol., 45, 189-202.

Märss, T. 2003. Paralogania from the Rootsiküla (Wenlock) and Paadla (Ludlow) stages of Estonia. Proc. Estonian Acad. Sci. Geol., 52, 98-112.

Märss, T. \& Karatajūtè-Talimaa, V. 2002. Ordovician and Lower Silurian thelodonts from Severnaya Zemlya Archipelago (Russia). Geodiversitas, 24, 381-404.

Märss, T. \& Miller, C. G. 2004. Thelodonts and distribution of associated conodonts from the Llandovery-lowermost Lochkovian of the Welsh Borderland. Palaeontology, 47, 12111266.

Märss, T., Caldwell, M., Gagnier, P.-Y., Goujet, D., Männik, P., Martma, T. \& Wilson, M. 1998a. Distribution of Silurian and Lower Devonian vertebrate microremains and conodonts in the Baillie-Hamilton and Cornwallis Island sections, Canadian Arctic. Proc. Estonian Acad. Sci. Geol., 47, 51-76.

Märss, T., Soehn, K. L. \& Wilson, M. V. H. 1998b. Microvertebrate-based correlations of the Llandovery-Wenlock boundary in some sections of the Selwyn and Franklinian sedimentary basins, northern Canada. In Circum-Arctic Palaeozoic Faunas and Facies. Warsaw, Poland, September 3-8, 1998 (Ginter, M. \& Wilson, M. V. H., eds), Ichthyolith Issues. Spec. Publ., 4, 37-39.

Märss, T., Turner, S. \& Karatajūtė-Talimaa, V. Handbook of Paleoichthyology: Vol. 1C. Agnatha. Thelodonti (Schultze, H.-P., ed.). Verlag Dr. Friedrich Pfeil, München (submitted).

Märss, T., Wilson, M. V. H. \& Thorsteinsson, R. 2002. New thelodont (Agnatha) and possible chondrichthyan (Gnathostomata) taxa established in the Silurian and Lower Devonian of the Canadian Arctic Archipelago. Proc. Estonian Acad. Sci. Geol., 51, 88-120.

Märss, T., Wilson, M. V. H. \& Thorsteinsson, R. 2006. Silurian and Lower Devonian thelodonts and putative chondrichthyans from the Canadian Arctic Archipelago (Cornwallis, BaillieHamilton, Devon, and Prince of Wales islands). Spec. Pap. Palaeontol., 75, 1-140.

Miller, G. \& Märss, T. 1999. A conodont, thelodont and acanthodian fauna from the Lower Přidoli (Silurian) of the Much Wenlock Area, Shropshire. Palaeontology, 42, 691-714.

Nestor, H. 1997. Silurian. In Geology and Mineral Resources of Estonia (Raukas, A. \& Teedumäe, A., eds), pp. 89-106. Estonian Academy Publishers, Tallinn.

Perens, R. \& Perens, H. 2004. Saaremaa hüdrogeoloogilise kaardi mõotkavas 1:200 000 seletuskiri. Eesti Geoloogiakeskus, Keila. 
Perens, R., Perens, H., Einmann, A. \& Eltermann, G. 1994. Saaremaa kompleksse geoloogilise kaardistamise mõotkavas 1:50 000 aruanne. I. Aruande tekst. Eesti Geoloogiakeskus, geoloogilise kaardistamise osakond, Keila.

Traquair, R. H. 1898. Report on fossil fishes collected by the Geological Survey of Scotland in the Silurian rocks of the South of Scotland. Trans. Roy. Soc. Edinburgh, Earth Sci., 39, 827-864.

Turner, S. 1991. Monophyly and interrelationships of the Thelodonti. In Early Vertebrates and Related Problems of Evolutionary Biology (Chang Mee-mann, Liu Yu-hai \& Zhang Guorui, eds), pp. 87-119. Science Press, Beijing.

Turner, S. 2000. New Llandovery to early Přidoli microvertebrates including Lower Silurian zone fossil, Loganellia avonia nov. sp., from Britain. In Palaeozoic Vertebrate Biochronology and Global Marine/Non-Marine Correlation. Final Report of IGCP 328 (Blieck, A. \& Turner, S., eds), Cour. Forschungsinst. Senckenberg, 223, 91-127.

Viira, V. \& Männik, P. 1997. Conodonts. In Geology and Mineral Resources of Estonia (Raukas, A. \& Teedumäe, A., eds), pp. 241-246. Estonian Academy Publishers, Tallinn.

Wilson, M. V. H. \& Caldwell, M. W. 1998. The Furcacaudiformes: a new order of jawless vertebrates with thelodont scales, based on articulated Silurian and Devonian fossils from Northern Canada. J. Vertebr. Paleontol., 18, 10-29.

\section{Telodondid (Agnatha) Kuressaare lademe (Ludlow, Ülem-Silur) basaalsetest kihtidest Eestis}

\section{Tiiu Märss}

On kirjeldatud telodonti Loganellia cuneata (Gross) ja püstitatud uued telodontide taksonid Paralogania perensae sp. nov., Nethertonodus laadjalaensis sp. nov. ja Longodus acicularis gen. et sp. nov. Viimast on vaadeldud sugukonnas Longodidae fam. nov. senitundmatust (nimetamata) seltsist alamklassis Thelodonti. Kirjeldatud telodondid on avastatud Saaremaa ja seda ümbritsevate saarte (Ruhnu, Kihnu) ning mandriosa (Varbla) puursüdamikest Eestis Kuressaare lademe (Ülem-Silur, Ludlow) Tahula kihtide alumisest osast. 